\title{
ЛОГІКА ВІДОБРАЖЕННЯ ТРАНСДИСЦИПЛІНАРНОСТІ В РЕАЛІЗАЦІЇ ЗАВДАНЬ БЕЗПЕРЕРВНОГО ПРОФЕСІЙНОГО РОЗВИТКУ РЕАБІЛІТОЛОГІВ
}

О. М. Шевцова

\author{
Національний медичний університет імені О. О. Богомольия
}

\begin{abstract}
Обговорено новітні підходи до безперервного професійного розвитку реабілітологів. Постулюється, що одним із найважливіших завдань сьогодення $€$ ефрективне забезпечення інтеграції та поглиблення конкретних знань в реабілітації, виходячи із сутності трансдисциплінарного підходу та прагнення відтворити цілісну наукову картину реабілітації. Також підкреслюється, що впровадження трансдисциплінарних принципів в охорону здоров'я потребує створення відповідного нового законодавства, стандартів, політики, стратегії та планів.
\end{abstract}

Ключові слова: трансдисциплінарність, реабілітологія, знання-орієнтовані інформаційні системи, реабілітація інвалідів, напрями використання трансдисциплінарності в реабілітації.

\section{LOGIC OF THE DISPLAY OF TRANSDISCIPLINARY EDUCATION IN THE REALIZATION OF REHABILITOLOGISTS CONTINUOUS PROFESSIONAL DEVELOPMENT PROBLEMS}

O. M. Shevtsova

\section{O. Bogomolets National Medical University}

\begin{abstract}
The latest approaches to the continuous professional development of rehabilitation specialists are discussed. It is postulated that one of the most important tasks of our time is the effective provision of integration and deepening of concrete knowledge in rehabilitation, based on the essence of the transdisciplinary approach and the desire to recreate the integral scientific picture of rehabilitation. It is also emphasized that the introduction of transdisciplinary health care requires the creation of appropriate new legislation, standards, policies, strategies and plans.
\end{abstract}

Key words: transdisciplinarity, rehabilitation, knowledge-oriented information systems, rehabilitation of disabled people, directions of using transdisciplinarity in rehabilitation.

\section{ЛОГИКА ОТОБРАЖЕНИЯ ТРАНСДИСЦИПЛИНАРНОСТИ В РЕАЛИЗАЦИИ ЗАДАЧ НЕПРЕРЫВНОГО ПРОФЕССИОНАЛЬНОГО РАЗВИТИЯ РЕАБИЛИТОЛОГОВ}

О. М. Шевцова

Национальный медицинский университет имени А. А. Богомольца

\begin{abstract}
Обсуждены новейшие подходы к непрерывному профессиональному развитию реабилитологов. Постулируется, что одной из важнейших задач современности является эффективное обеспечение интеграции и углубления конкретных знаний в реабилитации, исходя из сущности трансдисциплинарного подхода и стремления воссоздать целостную научную картину реабилитации. Также подчеркивается, что внедрение трансдисциплинарных принципов в здравоохранение требует создания соответствующего нового законодательства, стандартов, политики, стратегии и планов.
\end{abstract}

Ключевые слова: трансдисциплинарность, реабилитология, знание-ориентированные информационные системы, реабилитация инвалидов, направления использования трансдисциплинарности в реабилитации.

(C) О. М. Шевцова 
Вступ. Серед численних публікацій останніх років особливої уваги заслуговує осмислення та поступове впровадження логіки трансдисциплінарності в наукових дослідженнях та освіті. Цей інтерес цілком зрозумілий, якщо взяти до уваги, що сучасний етап розвитку науки та їі додатків носить очевидний трансдисциплінарний характер [2-4]. Більш того, парадигма, побудована на принципах трансдициплінарності, вперше передбачає побудову в доступному для огляду майбутньому єдиної системи знань, що забезпечує формалізовані постановку та вирішення конкретних завдань при виконанні комплексних проектів будь-якої складності. Підкреслимо, що трансдисциплінарність принципово відрізняється від міждисциплінарності. Остання пов'язана 3 перенесенням методів однієї наукової дисципліни в іншу. Навпаки, трансдисциплінарність стосується того, що може лежати між дисциплінами, за межами кожної окремої дисципліни.

На жаль, у практичній медицині й організації охорони здоров'я трансдисциплінарність ні з точки зору методології, ні з точки зору прикладних аспектів не знайшла належного відображення.

Мета роботи: обгрунтувати перспективні напрями розвитку трансдисциплінарності в реабілітології.

Результати та їх обговорення. Реабілітологія сьогодні має не тільки міжсекторальний і мультидисциплінарний характер, здійснюючи допомогу пацієнтам медичними працівниками різних напрямів, але й очевидний трансдисциплінарний тренд, що забезпечується участю в реабілітації фахівців iз різних секторів освіти, соціального захисту та інших сфер. Реабілітаційні послуги інтегруються в широкий діапазон установ, включаючи стаціонарні, амбулаторні, інтернатні установи та дома. Розглядаючи трансдисциплінарний аспект реабілітології, відзначимо, що його основний зміст і призначення складаються 3 інтеграції різних наукових дисциплін, їх синергетичної взаємодії за рахунок взаємопроникнення парадигм і конкретних поточних результатів кожної з дисциплін. Зазначена взаємодія відображає цілісність реального світу, будучи стимулом і одночасно гарантією успішності сучасних трансдисциплінарних досліджень i пов'язаних із ними практичних проектів [1].

Найбільш ексвізітним проявом трансдисциплінарності $€$ реабілітація інвалідів, для яких надзвичайно важливим слід визнати використання сучасних технологій і технічних допоміжних засо- бів. Беручи до уваги той факт, що індивідуальна мобільність є важливим елементом реабілітації, забезпечення реабілітаційних програм індивідуальної мобільності інвалідів із максимально можливим ступенем їхної самостійності набуває великого значення. Цього можливо досягти, використовуючи різні кібернетичні, інформаційні та інші технології, ілюструючи різні аспекти трансдисциплінарності.

Трансдисциплінарна парадигма передбачає побудову в доступному майбутньому загальної наукової картини світу або, що те ж саме, єдиної трансдисциплінарної системи знань, що забезпечує формалізовані постановку та вирішення конкретних завдань при виконанні комплексних проектів високої складності, соціальної значущості, конфліктності та конкурентності.

Розглянемо основні напрями використання трансдисциплінарності в реабілітації.

1. Ефективне забезпечення інтеграції та поглиблення конкретних знань в реабілітації, виходячи із сутності трансдисциплінарного підходу, та прагнення відтворити цілісну наукову картину реабілітації.

У свою чергу, перший напрям базується на таких трендах:

- побудова ефективної архітектури знання-орієнтованих інформаційних систем за допомогою таких розділів сучасної інформатики, як: knowledge-processing, прагматична модель мовної свідомості, віртуальна парадигма та іiі додатки;

- уніфікація принципів конструктивізації знань i їх уявлень. По суті даний тренд є одним із найбільш складних і важливих етапів формулювання трансдисциплінарного підходу в реабілітології. Це обумовлено не тільки складністю, великою розмірністю завдань і даних, надзвичайним об'ємом системно-аналітичної складової на тлі міждисциплінарних відмінностей, але й відсутністю методології міждисциплінарної і тим більше трансдисциплінарної взаємодії. Принципово, що реабілітологія представляє останній етап лікувально-діагностичного процесу, але шляхів до цього етапу досить багато та кожен із них має свої особливості. Важливо також врахувати, що необхідно не тільки використовувати дані попередніх і поточних досліджень на основі професійного управління знаннями (knowledge management), а й засобів їх методологічної та інформаційно-технологічної підтримки; 
когнітивної семантики, що має відобразити природну схему інтеграції знань фахівця в даному напряму медицини. Підкреслимо, що виконання трансдисциплінарних завдань у реабілітології (втім як і в усій медицині) утруднено через відмінності в словах і поняттях у суміжних дисциплінах. Великі труднощі можуть виникнути і при взаємодії 3 інвалідами, тобто з особами з порушенням функціональності, 3 поведінковими стереотипами та соціальними бар'єрами, що перешкоджають їх повній і ефективній участі в процесі нарівні з іншими.

2. Обгрунтування освітніх програм нового типу не тільки для того, щоб поліпшити реабілітаційні медико-соціальні послуги для людей із усіма типами порушень функціональності, в тому числі індивідів 3 порушеннями мовлення і / або слуху, порушеннями зору та психічного здоров'я. Вона буде заохочувати розвиток початкового та подальшого навчання фахівців і персоналу, що працюють в сфері абілітації та реабілітаційних послуг. Вона також буде заохочувати наявність знань і використання технічних допоміжних засобів і технологій, призначених для інвалідів, оскільки вони відносяться до абілітації та реабілітації.

3. Розроблення нових стандартів надання медичної допомоги з включенням трансдисциплінарних елементів.

4. Істотні зміни процедур оцінювання якості медичної допомоги в результаті залучення методів і підходів із інших дисциплін.

Підкреслимо ще один важливий аспект, пов'язаний 3 впровадженням трансдисциплінарності. Стратегія надання реабілітаційних послуг інвалідам має будуватися 3 урахуванням їх прав на абілітацію та реабілітацію, забезпеченням можливості наділення людей із інвалідністю максимальною незалежністю, повними фізичними, соціальними та професійними здібностями; повного включення та залучення в усі аспекти життя. 3 цією метою в стратегії розвитку реабілітаційної служби та післядипломного навчання мають бути ураховані перспективи державних програм щодо комплексних реабілітаційних послуг та програм, особливо в сфері охорони здоров'я, таким чином, щоб вони: а) починали реалізовуватися якомога раніше і були засновані на мультидисциплінарному та трансдисциплінарному оцінюванні потреб індивіда; б) забезпечували доступність для інвалідів якомога ближче до місць їхнього безпосереднього проживання, в тому числі в сільських місцевостях. Зрозуміло, трансдисциплінарна парадигма повинна сприяти інтеграції питань, пов'язаних із інвалідністю, як складової і невід'ємної частини відповідних стратегій сталого розвитку на всіх соціальних рівнях організації (національному, регіональному, обласному, районному). Необхідно створення відповідного нового законодавства, стандартів, політики, стратегії та планів. Вкрай важливими стають інформаційні, комунікаційні та інших служби.

\section{Висновки.}

1. Однією 3 найважливіших задач сьогодення $\epsilon$ ефективне забезпечення інтеграції та поглиблення конкретних знань в реабілітації, виходячи із сутності трансдисциплінарного підходу та прагнення відтворити цілісну наукову картину реабілітації.

2. Впровадження трансдисциплінарних принципів в охорону здоровя потребує створення відповідного нового законодавства, стандартів, політики, стратегії та планів.

\section{Література.}

1. Ананьев Б. Г. Человек как предмет познания / Б. Г. Ананьев. - СПб. : Питер, 2001. - 288 с.

2. Палагин А. В. К вопросу системно-онтологической интеграции знаний предметной области / А. В. Палагин, Н. Г. Петренко // Математичні машини і системи. - 2007. - № 3, 4. - С. 63-75.

3. Nicolescu B. Transdisciplinarity - past, present and future / Basarab Nicolescu // Moving Worldviews Conference Proceedings. - Leusden, the Netherlands : ETC/Compas, 2005. - P. 142-165.

4. Nicolescu B. Transdisciplinarity - theory and practice

Hampton Press. - 2008. - 320 c.

\section{References.}

1. Anan'ev, B. G. (2001) Chelovek kak predmet poznaniya [Man as an object of knowledge]. SPb: Piter.

2. Palagin, A. V., \& Petrenko, N. G. (2007) K voprosu sistemno-ontologicheskoi integratsii znanii predmetnoi oblasti. [To the question of system-ontological integration of domain knowledge]. Matematychni mashini i systemi [Mathematical Machines and Systems], 3, 4, 63-75.

3. Nicolescu B. (2005) Transdisciplinarity - past, present and future. In B. Haverkott, \& C. Reijntjes (Eds.), Moving Worldviews Conference Proceedings. Leusden, the Netherlands: ETC/Compas, 142-165.

4. Nicolescu, B. (Ed.) (2008) Transdisciplinarity - theory and practice. Cresskill: Hampton Press. 